\title{
Two morphotypes of tri-spine horseshoe crab, Tachypleus tri- dentatus (Leach, 1819) (Xiphosura Limulidae) in Indonesia and implications for species identification
}

\author{
Naila Khuril Aini', Erwyansyah Erwyansyah², Rahmat Kurnia ${ }^{3}$, Nurlisa Alias Butet ${ }^{3}$, Ali Mashar ${ }^{3}$, Zairion \\ Zairion $^{3}$, Peter Funch 4 , Hawis Madduppa ${ }^{6}$ \& Yusli Wardiatno*3,5,7
}
${ }^{1}$ Master Program in Aquatic Resources Management, Graduate School of IPB University, Kampus IPB Darmaga, Bogor 16680, West Java, Indonesia
${ }^{2}$ Ministry of Marine Affairs and Fisheries, Republic of Indonesia
${ }^{3}$ Department of Aquatic Resources Management, Faculty of Fisheries and Marine Sciences, IPB University, Kampus IPB Darmaga, Bogor 16680, West Java, Indonesia
${ }^{4}$ Department of Biology - Genetics, Ecology and Evolution, Aarhus University, Denmark
${ }^{5}$ Environmental Research Center - IPB University, Kampus IPB Darmaga, Bogor 16680, West Java, Indonesia
${ }^{6}$ Department of Marine Science and Technology, Faculty of Fisheries and Marine Sciences, IPB University, Kampus IPB Darmaga, Bogor 16680, West Java, Indonesia
${ }^{7}$ Center for Coastal and Marine Resources Studies - IPB University, Kampus IPB Baranangsiang, Bogor 16143, West Java, Indo- nesia
${ }^{*}$ Corresponding author, email: yusli@ipb.ac.id

\begin{abstract}
Of the four extant species of horseshoe crabs in the world (Xiphosura Limulidae), Indonesia have three species, i.e., Tachypleus tridentatus (Leach, 1819), T. gigas (O.F. Müller, 1785) and Carcinoscorpius rotundicauda (Latreille, 1802). The species identification based on morphology of especially the females of the two Tachypleus species can be difficult. This study aimed at evaluating morphological characters used in species determination of T. tridentatus and $T$. gigas. Two morphological characters for separating the two species are the number and position of immovable spines and the spinnerets on the opisthosomatic carapace. The study was conducted in Balikpapan coastal area in Indonesia. Two morphotypes of T. tridentatus were found. Of the 120 collected specimens, $13.33 \%$ had one immovable spine, while $86.67 \%$ had three immovable spines on the opisthosomatic carapace. The two morphotypes were found in both males and females. DNA barcoding of both males and females with two morphotypes confirmed that the specimens were T. tridentatus. Thus, three immovable spines at opisthosoma can still be used as a morphological characters for T. tridentatus identification, but another morphotype with only one spine is present. This makes the distinction between the females of the two Tachypleus species more difficult. However, spinnerets on the dorsal opisthosoma can still be used to separate them.
\end{abstract}

KEY WORDS Horseshoe crab; morphogenetics; molecular identificatication; species complex.

Received 10.03.2020; accepted 13.05.2020; published online 30.06.2020

\section{INTRODUCTION}

The four species of extant horseshoe crabs are the American horseshoe crab, Limulus polyphemus
(Linnaeus, 1758), restricted to Atlantic waters (Walls et al., 2002) and the three Asian horseshoe crabs (Carcinoscorpius rotundicauda (Latreille, 1802), Tachypleus gigas (O.F. Muiller, 1785), and 
Tachypleus tridentatus (Leach, 1819) (Lee \& Morton, 2005; Sekiguchi \& Shuster, 2009). All three species of Asian horseshoe crabs can be found in Indonesian coastal waters, distributed around Sumatra, Java, Kalimantan and Sulawesi (Rubiyanto, 2012; Mashar et al., 2017; John et al., 2018a, b; Vestbo et al., 2018).

The conservation status of L. polyphemus is vulnerable (VN) and the species has been intensively studied compared to $C$. rotundicauda, $T$. gigas, and Tachypleus tridentatus. Recently, T. tridentatus changed to endangered (EN) conservation status (IUCN, 2019) from data deficient (DD) (IUCN, 2015). The remaining two species of horseshoe crabs (C. rotundicauda and T. gigas) are categorised as data deficient conservation status (DD) (IUCN, 2015).

Since the number of studies of Asian horseshoe crabs are limited and their current geographic distribution is not fully known, it would be valuable to involve local communities living near the habitats of the horseshoe crabs in sampling and monitoring.

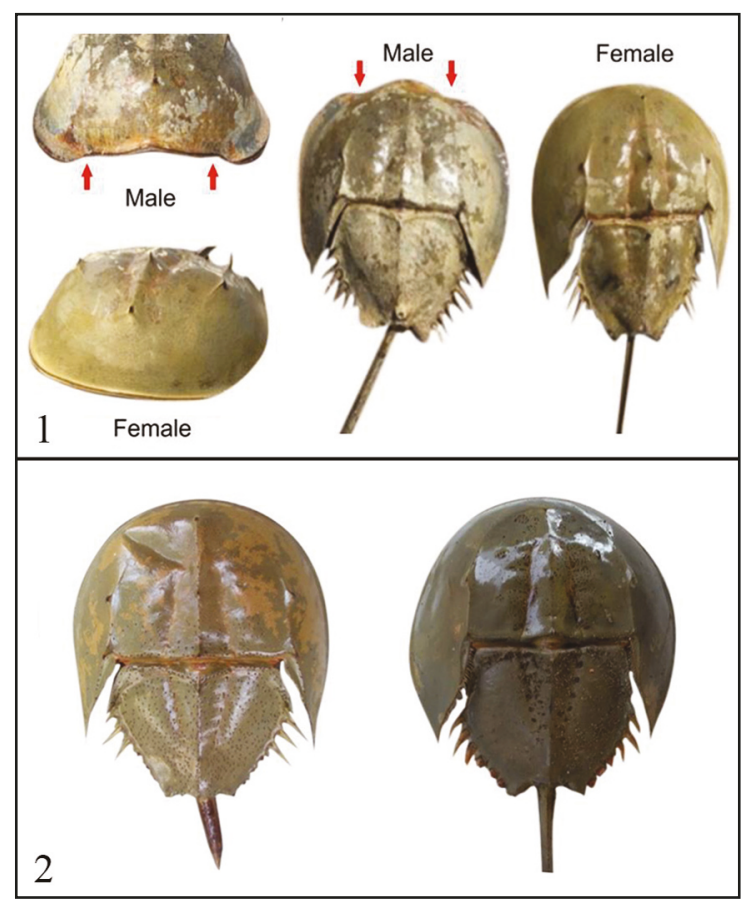

Figure 1. Male and female of Tachypleus tridentatus collected from Balikpapan coastal area, Indonesia. The prosoma in the male showed two clear symmetrical indentation as indicated by arrows. Figure 2. Dorsal view of female T. tridentatus (left) and T. gigas (right) showing smooth curves of prosoma which renders these two species as the same species.
However, in order to do this, knowledge on how to differentiate between the three Asian species using morphological characters is required. Determining sex for $T$. tridentatus can be done by abscertaining the presence of two clear symmetrical indentations in prosoma for males and their absences of it for females (Fig. 1). The indentations can be used to distinguish between male Tachypleus tridentatus and T. gigas. However, the frontal margin (smooth curve of prosoma) in the female of the two species look the same (Fig. 2).

Monophyly in the genus Tachypleus is strongly supported by phylogenetic analysis using molecular data (Obst el al., 2012), and the two species of Tachypleus are charactarized by a triangular telson in cross-section with a dorsal keel and a ventral groove and can easily be distinguished from the mangrove horseshoe crab Carcinoscorpius rotundicauda that has instead a subtriangular telson with round ridges in cross-section. Also, C. rotundicauda is small-sized compared to the two Tachypleus species (Yamasaki, 1988). For T. tridentatus, morphological characters used in previous studies are three immovable spines located on the dorsal posterior margin of ophisthosoma and spinnerets scattered on the dorsal opisthosomatic carapace (Pocock, 1902; Waterman, 1958; Yamasaki, 1988; Liao et al., 2002; Chiu \& Morton, 2003). The common name tri-spine horsehoe crab used for T. tridentatus actually refers to the presence of the three immovable spines. The morphological characters used for identifying $T$. gigas is the presence of only one median immoveable spine pointed posteriorly, and a smooth opisthosomatic carapace except for the cardiac region (Yamasaki, 1988). This study aimed at evaluating the morphological characters used to differentiate between $T$. tridentatus and $T$. gigas and to provide a practical guide for species determination in voluntary monitoring by local communities living near the horseshoe crab habitats.

\section{MATERIAL AND METHODS}

\section{Study area and specimen collection}

The study was conducted in at fish landing sites of Balikpapan coastal area, Indonesia (Fig. 3). Horseshoe crabs were collected with help from 
local fishermen using gillnet and trawl-like fishing gear. A total of 105 individuals of T. tridentatus were collected from 1 January to 31 March 2018 and 15 additional individuals were obtained from 23 October to 18 November 2019. Two specimens of Tachypleus gigas were collected for morphological comparison with $T$. tridentatus.

\section{Morphological identification and DNA bar- coding}

All collected specimens were identified morphologically following Pocock (1902) and Yamasaki (1988). Hemolymph from four specimens of $T$. tridentatus were sampled to validate the species identification using molecular approach. The four specimens included males and females with one and three spines on the posteriormost dorsal opisthosoma. Genomic DNA was extracted using the GeneAID Kit as instructed from the supplier. A cytochrome c oxidase I (CO1) mitochondrial gene fragment were amplified using the primer pairs designed by Nurlisa Alias Butet (2013; unpublished data). PCR amplification was performed in a SEDI Thermo Cycler RM G with $5 \mu$ l genomic DNA, $4.5 \mu 1 \mathrm{H} 2 \mathrm{O}, 12.5$ taq polymerase $12.5 \mu 1$, $\mathrm{CO} 1$ forward primers $1.5 \mu \mathrm{l}$, reverse $\mathrm{CO} 1$ primers
1.5 $\mu$ l. Stages of PCR include pre denaturation $\left(95^{\circ} \mathrm{C}\right.$ for $\left.5 \mathrm{~min}\right)$, denaturation $\left(94^{\circ} \mathrm{C}\right.$ for $\left.45 \mathrm{sec}\right)$, annealing $\left(54^{\circ} \mathrm{C}\right.$ for $\left.1 \mathrm{~min}\right)$, elongation $\left(72^{\circ} \mathrm{C}\right.$ for 1 $\mathrm{min})$ and post elongation $\left(72^{\circ} \mathrm{C}\right.$ for $\left.1 \mathrm{~min}\right)$. The stages of denaturation, annealing and elongation were carried out in 35 cycles. The quality of PCR products were tested on $1.2 \%$ agarose gels, and those with amplified products were sent to sequencing facility by Genetika Science Indonesia. Forward and reverse nucleotide sequences were aligned with ClustalW in MEGA version 7 software (Kumar et al., 2016). The aligned sequences were blasted in GenBank using the National Center for Biotechnology Information (NCBI) (Zhang et al., 2000, Morgulis et al., 2008) for species identification and comparison.

\section{RESULTS AND DISCUSSIONS}

Of the 120 collected specimens of $T$. tridentatus from Balikpapan coastal waters, $13.33 \%$ of them had one mid-dorsal immovable spine on the posterior margin of the opisthosomatic carapace, while $86.67 \%$ of them had three immovable spines in the posterior of opisthosoma. The two morphotypes were found in both males and females (Fig. 4).

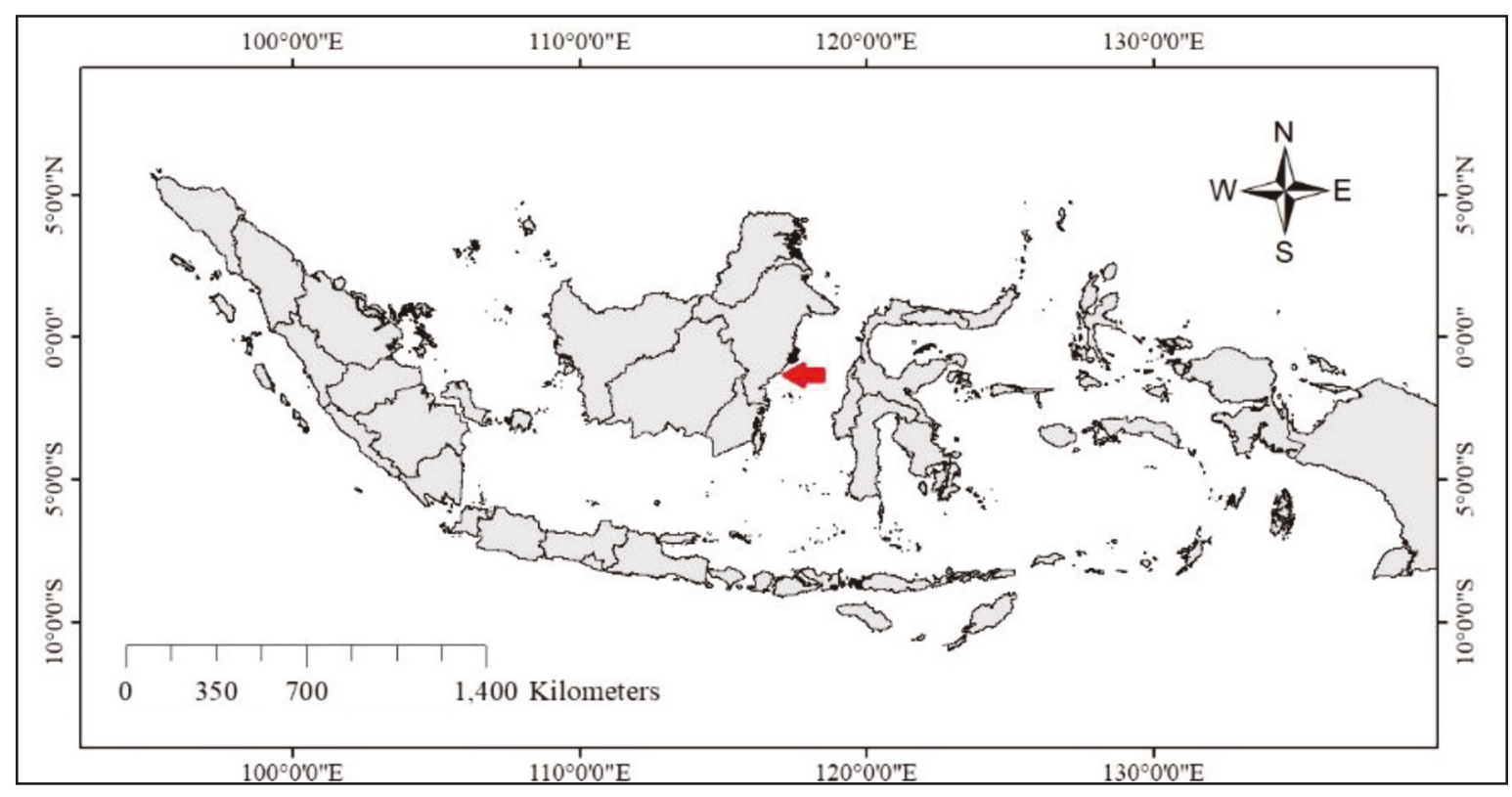

Figure 3. Sampling location in Balikpapan coastal area, Indonesia as indicated by the red arrow. 
Successful PCR and sequence data was obtained from four T. tridentatus representing two males and two females of the two morphotypes. Blasting of 551-593 bp long CO1 gene fragments of all four samples showed $99 \%$ similarity with sequences of Tachypleus tridentatus in the NCBI database (access code JQ739210.1, FJ860267.1, and U09387.1). Consequently, the presence of the three immovable spines at the posteriormost opisthosoma of $T$. tridentatus could be potentially be used as a morphological character for species identification with precaution, although it was used succesfully in many previous studies (Pocock, 1902; Waterman, 1958; Yamasaki, 1988; Liao et al., 2002; Chiu \& Morton 2003; Muslihah, 2004; Yang \& Ko, 2015; Dolejš \& Vaňousová, 2015; Hu et al., 2015). However, the presence of spinnerets on the dorsal opisthosomatic carapace of T. tridentatus compared to T. gigas with a smooth surface except for the cardiac region was consistently species-specific (Figs. $5,6)$.

This study was based on specimens collected in the Balikpapan coastal area, Indonesia. It would be interesting to study possibly variability in the number and position of posterior immovable spines in T. tridentatus from other geographic areas to investigate their variation, either general or a local variation. A previous study that used morphometric analysis of body shape in three species of horseshoe crabs failed to show regional intraspecific variation in females of C. rotundicauda and T. gigas, however males of $C$. rotundicauda did show variation (Faurby et al., 2011).

\section{CONCLUSIONS}

It can be concluded that the distribution pattern of spinnerets on the dorsal opisthosomatic carapace could be potential to be used as a morphological character to distinguish between $T$. tridentatus from $T$. gigas, while the number and position of the immoveable spines as a brace character.

\section{ACKNOWLEDGEMENTS}

The research is funded by Research Center for Oceanography, Indonesian Institute of Sciences (PPO-LIPI) through Demand-Driven Research

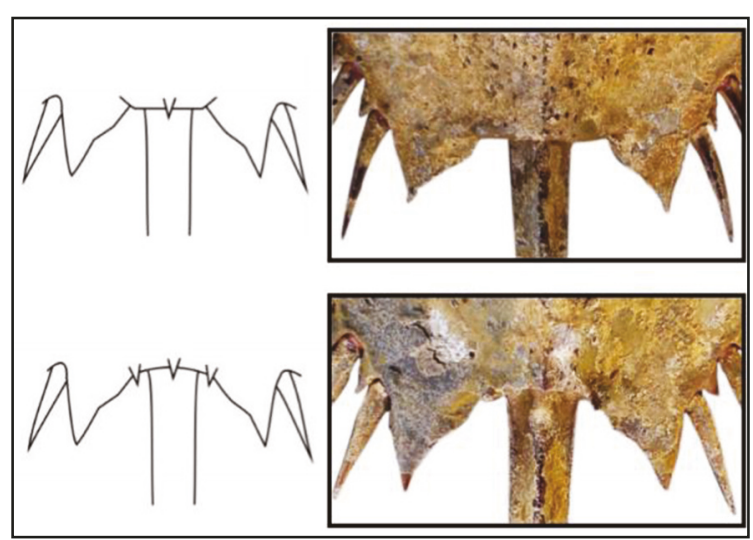

Figure 4. Two morphotypes of Tachypleus tridentatus from Balikpapan coastal area, Indonesia. The dorsal posteriormost opisthosoma carries either one or three spines.

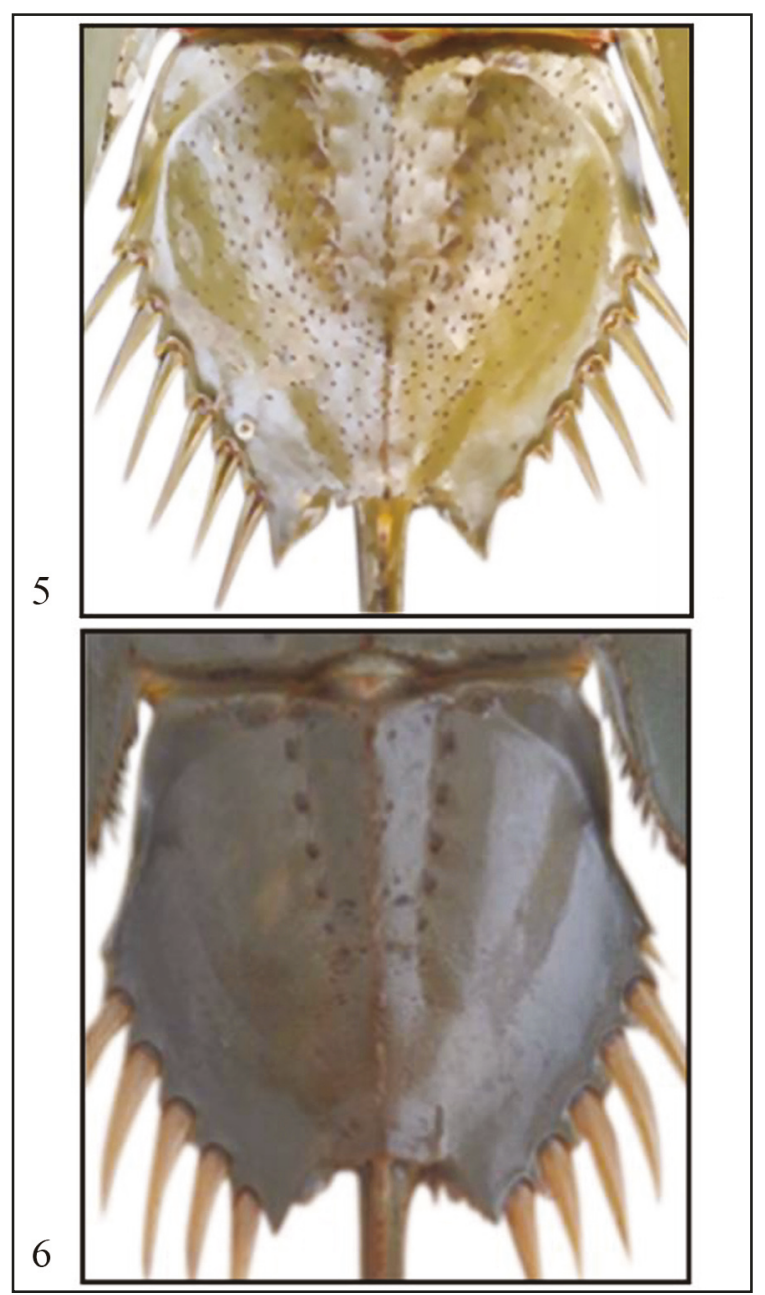

Figures 5, 6. Comparison of the dorsal opisthosoma of Tachypleus tridentatus (Fig. 5) and T. gigas (Fig. 6) from Balikpapan coastal area, Indonesia. 
Fund Contract No. B-5063/IPK.2/KS.02/III/2019 to YW and IPB University through PMDSU scheme Contract No. 6623/IT3.L1/PN/2019 to YW (following contract between IPB University and Ministry of Research, Technology and Higher Education No. 261/SP2H/LT/DRPM/20190). The authors want to thank to those who helped in sample collection and laboratory works: Heri Seputro, Rani Nuraisah, and Ananingtyas Septia Darmarini. Fahresa Nugraheni Supadminingsih is thanked for providing the photo of a female $T$. gigas.

\section{REFERENCES}

Chiu H.M.C. \& Morton B., 2003. The morphological differentiation of two horseshoe crab species, Tachypleus tridentatus and Carcinoscorpius rotundicauda (Xiphosura), in Hong Kong with a regional Asian comparison. Journal of Natural History, 37: 23692382. https://doi.org/10.1080/00222930210149753

Dolejš P. \& Vaňousová K., 2015. A collection of horseshoe crabs (Chelicerata: Xiphosura) in the National $\mathrm{Mu}-$ seum, Prague (Czech Republic) and a review of their immunological importance. Arachnologische Mitteilungen, 49: 1-9. https://doi.org/10.5431/aramit4901

Faurby S., Nielsen K.K., Bussarawit S., Intanai I., Cong N.V., Pertoldi C. \& Funch P., 2011. Intraspecific shape variation in horseshoe crabs: the importance of sexual and natural selection for local adaptation. Journal of Experimental Marine Biology and Ecology, 407: 131-138. https://doi.org/ 10.1016/j.jembe. 2011. 05.025

Hu M., Kwan B.K.Y., Wong Y., Cheung S.G. \& Shin P.K.S., 2015. Population structure and growth of juvenile horseshoe crabs Tachypleus tridentatus and Carcinoscorpius rotundicauda (Xiphosura) in Southern China. In: Carmichael R.H., Botton M.L., Shin P.K.S. \& Cheung SG (Eds), Changing Global Perspectives on Horseshoe Crab Biology, Conservation and Management, Springer, Cham. 167-180. https:// doi.org/10.1007/978-3-319-19542-1_8

IUCN, International Union for Conservation of Nature, 2015. Red list of threatened species. www. Iucnredlist.org.

IUCN, International Union for Conservation of Nature., 2019. Red list of threatened species. www. Iucnredlist.org.

John A.B., Nelson B.R., Hassan I.S., Cheung S.G., Wardiatno Y., Dash B.P., Tsuchiya K., Iwasaki Y. \& Pati S., 2018a. A review on fisheries and conservation status of Asian horseshoe crabs. Biodiversity and Conservation, 27: 3573-3578. https://doi.org/10.1007/ s10531-
John A.B., Nelson B.R., Hassan I.S., Cheung S.G., Wardiatno Y., Dash B.P., Tsuchiya K., Iwasaki Y. \& Pati S., 2018b. Correction to: A review on fisheries and conservation status of Asian horseshoe crabs. Biodiversity and Conservation, 27: 3845. https://doi.org/ 10.1007/s10531-018-1650-7.

Kumar S., Stecher G. \& Tamura K., 2016. MEGA7: Molecular evolutionary genetic analysis version 7.0 for bigger datasets. Molecular Biology and Evolution, 33: 1870-1874. https://doi.org/10.1093/molbev /msw054

Lee C.N. \& Morton B., 2005. Experimentally derived estimates of growth by juvenile Tachypleus tridentatus and Carcinoscorpius rotundicauda (Xiphosura) from nursery beaches in Hongkong. Journal of Experimental Marine Biology and Ecology, 318: 39-49. https: //doi.org/10.1016/j.jembe.2004.12.010

Liao Y., Li X.M. \& Hong S.G., 2002. Morphology of sallow horseshoe crab (Tachypleus tridentatus). Acta Zoologica Sinica, 48: 93-99.

Mashar A., Butet N.A., Juliandi B., Qonita Y., Hakim A.A., \& Wardiatno Y., 2017. Biodiversity and distribution of horseshoe crabs in Northern Coast of Java and Southern Coast of Madura. IOP Conference Series: Earth and Environmental Science, 54: 1-8. https://doi.org/10.1088/1755-1315/54/1/012076

Morgulis A., Coulouris G., Raytselis Y., Madden T.L., Agarwala R. \& Schäffer A.A., 2008. Database indexing for production MegaBLAST searches. Bioinformatics, 24: 1757-1764. https://doi.org/10.1093/bio informatics/btn 322

Muslihah., 2004. Some reproductive biological aspects of the horseshoe crab Tachypleus gigas in Mayangan waters, Subang District, West Java. Master Thesis. Bogor Agricultural University, Bogor.

Obst M., Faurby S., Bussarawit S. \& Funch P., 2012. Molecular phylogeny of extant horseshoe crabs (Xiphosura, Limulidae) indicates Paleogene diversification of Asian species. Molecular Phylogenetics and Evolution, 62: 21-26. https://doi.org/10.1016/j. ympev.2011.08.025

Pocock R.I., 1902. The taxonomy of recent species of Limulus. The Annals and Magazine of Natural History, 9: 256-266. https://doi.org/10.1080/ 0022293 0208678582

Rubiyanto E., 2012. Study on the population of horeseshoe crabs (Xiphosura) in Kuala Tungkal waters Tanjung Jabung Barat District, Jambi. Master Thesis. University of Indonesia, Jakarta.

Sekiguchi K. \& Shuster C.N. Jr., 2009. Limits on the global distribution of horseshoe crabs (Limulacea): lessons learned from two lifetimes of observations: Asia and America. In: Tanacredi J.T., Botton M.L. \& Smith D.R. (Eds.), Biology and Conservation of Horseshoe Crabs. Springer, New York. 5-24. 
Vestbo S., Obst M., Quevedo Fernandez F.J., Intanai I. $\&$ Funch P., 2018. Present and potential future distributions of Asian horseshoe crabs determine areas for conservation. Frontiers in Marine Science, 5: 164. https://doi.org/10.3389/fmars.2018.00164

Walls E.L., Berkson J. \& Smith S.A., 2002. The horseshoe crab, Limulus polyphemus: 200 million years of existence, 100 years of study. Reviews in Fisheries Science, 10: 39-73. https://doi.org/10.1080/20026491051677

Waterman T.H., 1958. On the doubtful validity of Tachypleus hoeveni Pocock, an Indonesian horseshoe crab (Xiphosura). Postilla Yale Peabody Museum of Natural History, 36: 1-17.
Yamasaki T., 1988. Taxonomy. In: Sekiguchi K. (Ed.), Biology of Horseshoe Crabs, Science House. Tokyo. $10-21$.

Yang K.C. \& Ko H.S., 2015. First record of tri-spine horseshoe crab, Tachypleus tridentatus (Merostomata: Xiphosurida: Limulidae) from Korean Waters. Animal Systematic, Evolution and Diversity, 31: 42- 45. http://dx.doi.org/10.5635/ASED.2015.31.1 .042

Zhang Z., Schwartz S., Wagner L. \& Miller W., 2000. A greedy algorithm for aligning DNA sequences. Journal of Computational Biology, 7: 203-214. https:// doi.org/10.1089/10665270050081478 